\title{
Impact of Customer Orientation, Service Orientation, Service Quality, Service Encounter Quality and Perceived Value towards Customers Satisfaction and Behavioural Intention: In Retail Context
}

\author{
Lau Wee Ming \\ SEGi College Sarawak \\ Hosea Lim Vui Chung \\ SEGi College Sarawak \\ Diana Atton ak Paul \\ SEGi College Sarawak
}

\begin{abstract}
Does customer satisfaction and behavioural intention directly influence by customer orientation, service orientation, service quality, service encounter quality, perceived value towards? In order to address this question, a survey was conducted in different grocery stores across the city. At the same time, this research also tends to examine whether the western oriented service evaluation model is applicable in non-western country. This study also proposed to examine the direct relationship without the existence of customer satisfaction and service quality as mediator. The outcomes of the analyses were used to determine the acceptance or rejection of the proposed hypotheses. With the positive relationship between the independent variables and dependent variables, all the generated hypotheses proposed in this research were accepted and approved.
\end{abstract}

Keywords: Customer Orientation, Service Orientation, Service Quality, Service Encounter Quality, Perceived Value, Customer Satisfaction, Behavioral Intention, Retail

\section{Introduction}

In today's business world, the awareness of service quality and customer satisfaction can be observe in multiple industries as these elements had been identified as one of the contributor in developing or sustaining the company's competitive advantages (Schlesinger \& Heskett, 1991). Nevertheless, these components have also become one of the essential fundamentals for retail industry in pursuing higher competitive advantages (Kandampully, 2010). There are lots of researches had been done by the researchers previously to examine and understand the relationship between customer satisfaction and perceived value (Fornell et al., 1996), perceived service quality and customer satisfaction (Cronin and Taylor, 1992; Andreassen 
and Lindestad, 1998) as well as the relationship between customer satisfaction and behavioural intentions (Bagozzi, 1992).

Basically, this research paper comprises of ten different research objectives which aim to examine a cluster of variables that impacts the customers' service evaluation process. The research objectives are as follow:

1. To determine the relationship between customer orientation (CO) and customer satisfaction.

2. To determine the relationship between customer orientation $(\mathrm{CO})$ and behaviour intentions (BI).

3. To determine the relationship between service orientation (SO) and customer satisfaction.

4. To determine the relationship between service orientation (SO) and behaviour intentions (BI).

5. To determine the relationship between service quality (SQ) and customer satisfaction.

6. To determine the relationship between service quality (SQ) and behaviours intentions (BI).

7. To determine the relationship between service encounter quality (SEQ) and customer satisfaction.

8. To determine the relationship between service encounter quality (SEQ) and behaviour intentions $(\mathrm{BI})$.

9. To determine the relationship between perceived value (VAL) and customer satisfaction.

10. To determine the relationship between perceived value (VAL) and behaviours intentions (BI).

\section{Conceptual Framework}

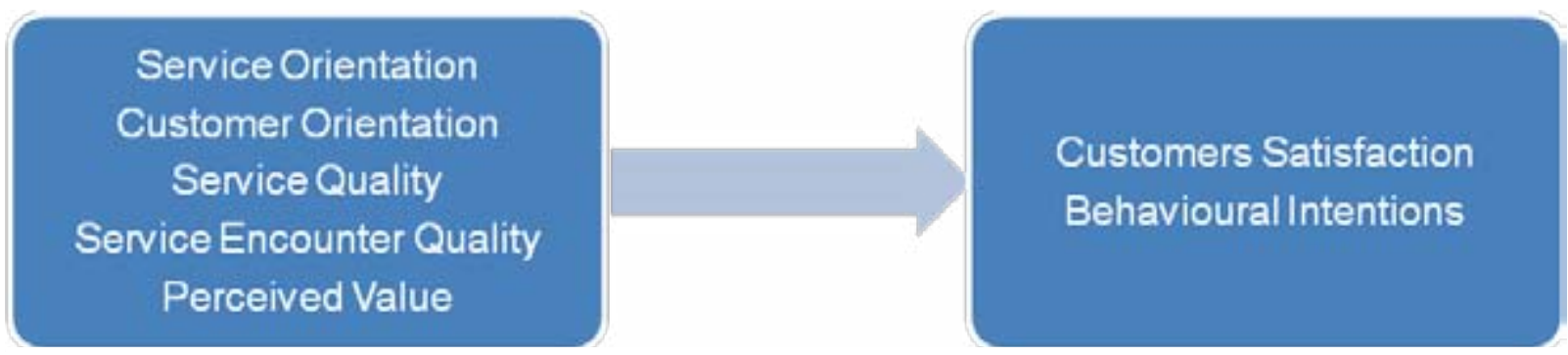

Figure 1: Conceptual Framework for Independent Variables and Dependent Variables 


\section{Literature Review}

Every organisation has its own preferable business orientation such as goal orientation, customer orientation, marketing orientation and so on. All the mentioned orientation served the same purpose; that is to generate more sales, more profit and help the company to develop or sustain their competitive advantages. The term "service orientation" had received much discussion due to the contrast in defining it by the scholars. Lytle and Timmerman (2006) had defined service orientation as "an organisation-wide embracement of a basic set of relatively enduring organisational policies, practices, and procedures intended to support and reward service-giving behaviours that create and deliver service excellence". Lytle and Timmerman's definition wassupported by others researchers too, with the statement claiming that organisation with service oriented policy will do their best in satisfying customers, create and deliver customer value (Heskett et al., 1997; Hennig-Thurau et al., 2002).

Nowadays, the level of delivered service quality had been seen as part of the essential strategy if an organisation wishes to outperform the others (Dawkins and Reichheld, 1990; Reichheld and Sasser; 1990; Zeithaml et al., 1990). Service sector has grown dramatically over the years and it is one of the major contributors in world GNP. Service sectors such as aviation industry and retailing industry are completely affected by the dynamic environment factors. These factors are: government rules and regulation, changes in public's interests, business trends, internationalization, and advances in technology (Hoffman et al., 1995; Rust and Oliver, 1994). Due to the deregulated and competitive markets, delivering quality services had become service marketers' primary concern (Fisher, 1991).

Nowadays, customer values have become one of the most important elements in building an organisation's competitive advantage (Woodruff, 1997) and as a reference for predicting the customers' purchasing behaviour (Chen and Dubinsky, 2003). Moreover, Ravald and Grönroos (1996) also viewed value as a significant part in relationship marketing.

The importance of evaluating and managing customer satisfaction has been recognized widely either in general or in the sphere of services (Tikkanen et al., 2000). Customer satisfaction has become one of the issues that awoke most interest in the marketing literature because it plays a key role in a successful business strategy (Gómez et al., 2004). Increased in price competition and reduced loyalty has become very common as the markets are getting increasingly competitive (Patterson, 2004).

\section{Research Methodology}

In this research, descriptive research had been selected as the only research design which means this is a single-stage study. According to Churchill and Iacobucci (2009), descriptive study is more firm and structured.

\section{Population and Sampling Method}

Since this research aim to understand the perceptions of customers' evaluation process in Malaysia, the city central of Kuching is selected. Kuching is one of the cities located in Sarawak, Malaysia. The central city of Kuching has approximately population of 277,100 people (DBKU, 2011). By applying the formula presented by Luck et al. (1987), the minimum sample size for the data collection in this city is 288. On the other hand, 
convenience sampling technique has been selected as the method for distributing the questionnaires. Saunders et al. (2003) defined convenience or haphazard sampling as a technique that select the cases randomly. This technique also had been identified as the easiest technique.

\section{Instrument for Questionnaire}

The distributed questionnaire consists of two parts: Part A (demographic factors) and Part B (multiple questions for the measurement of customer orientation, service orientation, service quality, service encounter quality, perceived value, customer orientation and behavioural intentions).

\section{Data Analysis}

\section{Descriptive Analyses}

Pelosi et al. (2000) and Kassim (2001) defined descriptive analysis as a tool to transform the raw data into a form that can be understand and interpret easily. Descriptive statistics encompass of measurement for central tendency, confidence intervals and measurements for dispersion (Brace et al., 2006).

\section{Pearson Correlation}

Pearson correlation was employed to measure the strength and orientation relationship that exists between two variables (Laerd Statistics, n.d.). The symbol $r$ is denoted the correlation value. With the obtained $r$ value after the analysis, the value can be group under 5 categories: no relationship $(\mathrm{r}=0.0 \sim 0.2)$, slight relationship $(\mathrm{r}=0.2 \sim 0.4)$, substantial relationship $(\mathrm{r}=0.4$ $\sim 0.6)$, strong relationship $(\mathrm{r}=0.6 \sim 0.8)$ and very strong relationship $(\mathrm{r}=0.8 \sim 1.0)$.

\section{Linear Regression}

Linear regression is the next step and final stages for data analysis in this research. Linear regression was conducted in this research to determine the main factors among independent variables (Sekaran and Bougie, 2010).

\section{Research Findings}

\section{Respondent Profile}

The table shown below presents the respondents' profile of this research with frequency and percentage.

Table I: Demographic Factors

\begin{tabular}{|l|l|c|c|}
\hline \multicolumn{2}{|c|}{ Demographic Parameter } & Frequency & Percent \\
\hline \multirow{3}{*}{ Gender } & Male & 147 & $51.0 \%$ \\
\cline { 2 - 4 } & Female & 141 & $49.0 \%$ \\
\hline \multirow{4}{*}{ Age } & $18-28$ & 135 & $46.9 \%$ \\
\cline { 2 - 4 } & $29-38$ & 84 & $29.2 \%$ \\
\cline { 2 - 4 } & $39-48$ & 50 & $17.4 \%$ \\
\cline { 2 - 4 } & $49-58$ & 16 & $5.6 \%$ \\
\cline { 2 - 4 } & 59 and above & 3 & $1.0 \%$ \\
\hline \multirow{5}{*}{ Marital Status } & Single & 159 & $55.3 \%$ \\
\cline { 2 - 4 } & Married & 115 & $39.9 \%$ \\
\cline { 2 - 4 } & Divorced & & $3.8 \%$ \\
\hline
\end{tabular}




\begin{tabular}{|l|l|c|c|}
\hline & Widowed & 3 & $1.0 \%$ \\
\hline \multirow{5}{*}{ Education Level } & SPM & 35 & $12.2 \%$ \\
\cline { 2 - 4 } & STPM & 37 & $12.8 \%$ \\
\cline { 2 - 4 } & Diploma & 94 & $32.6 \%$ \\
\cline { 2 - 4 } & Degree & 98 & $34.0 \%$ \\
\cline { 2 - 4 } & Master & 19 & $6.6 \%$ \\
\cline { 2 - 4 } & Others & 5 & $1.7 \%$ \\
\hline \multirow{5}{*}{ Race } & Malay & 63 & $21.9 \%$ \\
\cline { 2 - 4 } & Chinese & 152 & $52.8 \%$ \\
\cline { 2 - 4 } & Indian & 32 & $11.1 \%$ \\
\cline { 2 - 4 } & Others & 41 & $14.2 \%$ \\
\hline & Below RM 1,000 & 98 & $34.0 \%$ \\
\cline { 2 - 4 } & RM 1,001-RM 2,000 & 57 & $19.8 \%$ \\
\cline { 2 - 4 } & RM 2,001 - RM 3,000 & 69 & $24.0 \%$ \\
\cline { 2 - 4 } & RM 3,001 - RM 4,000 & 47 & $16.3 \%$ \\
\cline { 2 - 4 } & RM 4,001 - RM 5,000 & 11 & $3.8 \%$ \\
\cline { 2 - 4 } & RM 5,001 and above & 6 & $2.1 \%$ \\
\hline
\end{tabular}

\section{Means and Standard Deviation}

Means and standard deviation for all the variables in this study are presented in the table below.

Table II: Mean and Standard Deviation for All Variables.

\begin{tabular}{|l|c|c|}
\hline & Mean & Std. Deviation \\
\hline Customer Orientation & 4.02 & 1.22 \\
\hline Service Orientation & 4.04 & 1.25 \\
\hline Service Quality & 4.05 & 1.18 \\
\hline Service Encounter Quality & 4.05 & 1.18 \\
\hline Perceived Value & 4.14 & 1.24 \\
\hline Customer Satisfaction & 4.10 & 1.24 \\
\hline Behavioural Intention & 4.05 & 1.30 \\
\hline
\end{tabular}

\section{Pearson Correlation}

The results of Pearson correlation for all the variables are shown in the table below.

Table III: Pearson Correlation for all variables

\begin{tabular}{|l|c|c|}
\hline \multicolumn{1}{|c|}{ Variables } & Customer Satisfaction & Behavioural Intention \\
\hline Customer Orientation & $.842^{* *}$ & $.839^{* *}$ \\
\hline Service Orientation & $.801^{* *}$ & $.802^{* *}$ \\
\hline Service Quality & $.840^{* *}$ & $.855^{* *}$ \\
\hline Service Encounter Quality & $.860^{* *}$ & $.840^{* *}$ \\
\hline Perceived Value & $.838^{* *}$ & $.804^{* *}$ \\
\hline
\end{tabular}

**. Correlation is significant at the 0.01 level (2-tailed). 


\section{Linear Regression}

The tables below show the results of regression for all the relationship between independent variables and dependent variables.

Table IV: Linear Regression for Customer Orientation towards Customer Satisfaction

\begin{tabular}{|l|c|}
\hline \multirow{2}{*}{ Variables } & Customer Orientation \\
\cline { 2 - 2 } Customer Orientation & $0.842^{* *}$ \\
\hline $\mathrm{R}$ & 0.842 \\
\hline R Square & 0.708 \\
\hline Adjusted R Square & 0.707 \\
\hline Durbin Watson & 1.780 \\
\hline
\end{tabular}

** Significant at least at $\mathrm{p}<0.05$

Table V: Linear Regression for Service Orientation towards Customer Satisfaction

\begin{tabular}{|l|c|}
\hline \multirow{2}{*}{ Variables } & Customer Orientation \\
\cline { 2 - 2 } Service Orientation & $0.801^{* *}$ \\
\hline R & 0.801 \\
\hline R Square & 0.642 \\
\hline Adjusted R Square & 0.641 \\
\hline Durbin Watson & 1.908 \\
\hline
\end{tabular}

** Significant at least at $\mathrm{p}<0.05$

Table VI: Linear Regression for Service Quality towards Customer Satisfaction

\begin{tabular}{|l|c|}
\hline \multirow{2}{*}{ Variables } & Customer Orientation \\
\cline { 2 - 2 } Service Quality & B \\
\hline R & $0.840^{* *}$ \\
\hline R Square & 0.840 \\
\hline Adjusted R Square & 0.705 \\
\hline Durbin Watson & 0.704 \\
\hline
\end{tabular}

** Significant at least at $\mathrm{p}<0.05$

Table VII: Linear Regression for Service Encounter Quality towards Customer Satisfaction

\begin{tabular}{|l|c|}
\hline \multirow{2}{*}{ Variables } & Customer Satisfaction \\
\cline { 2 - 2 } Service Encounter Quality & B \\
\hline R & $0.860^{* *}$ \\
\hline R Square & 0.860 \\
\hline Adjusted R Square & 0.740 \\
\hline Durbin Watson & 0.739 \\
\hline
\end{tabular}

** Significant at least at $\mathrm{p}<0.05$ 
Table VIII: Linear Regression for Perceived Value towards Customer Satisfaction

\begin{tabular}{|l|c|}
\hline \multirow{2}{*}{ Variables } & Customer Satisfaction \\
\cline { 2 - 2 } & B \\
\hline Perceived Value & $0.838^{* *}$ \\
\hline R Square & 0.838 \\
\hline Adjusted R Square & 0.703 \\
\hline Durbin Watson & 0.702 \\
\hline
\end{tabular}

** Significant at least at $\mathrm{p}<0.05$

Table IX: Linear Regression for Customer Orientation towards Behavioural Intentions

\begin{tabular}{|l|c|}
\hline \multirow{2}{*}{ Variables } & Behavioural Intentions \\
\cline { 2 - 2 } Customer Orientation & $0.839^{* *}$ \\
\hline R & 0.839 \\
\hline R Square & 0.705 \\
\hline Adjusted R Square & 0.704 \\
\hline Durbin Watson & 2.007 \\
\hline
\end{tabular}

** Significant at least at $\mathrm{p}<0.05$

Table X: Linear Regression for Service Orientation towards Behavioural Intentions

\begin{tabular}{|l|c|}
\hline \multirow{2}{*}{ Variables } & Behavioural Intentions \\
\cline { 2 - 2 } & B \\
\hline Service Orientation & $0.802^{* *}$ \\
\hline R & 0.802 \\
\hline R Square & 0.642 \\
\hline Adjusted R Square & 0.641 \\
\hline Durbin Watson & 1.956 \\
\hline
\end{tabular}

** Significant at least at $\mathrm{p}<0.05$

Table XI: Linear Regression for Service Quality towards Behavioural Intentions

\begin{tabular}{|l|c|}
\hline \multirow{2}{*}{ Variables } & Behavioural Intentions \\
\cline { 2 - 2 } Service Quality & $0.855^{* *}$ \\
\hline R & 0.855 \\
\hline R Square & 0.730 \\
\hline Adjusted R Square & 0.730 \\
\hline Durbin Watson & 1.903 \\
\hline
\end{tabular}

** Significant at least at $\mathrm{p}<0.05$

Table XII: Linear Regression for Service Encounter Quality towards Behavioural Intentions

\begin{tabular}{|l|c|}
\hline \multirow{2}{*}{ Variables } & Behavioural Intentions \\
\cline { 2 - 2 } Service Encounter Quality & $0.840^{* *}$ \\
\hline $\mathrm{R}$ & 0.840 \\
\hline R Square & 0.706 \\
\hline Adjusted R Square & 0.705 \\
\hline Durbin Watson & 1.893 \\
\hline
\end{tabular}

** Significant at least at $\mathrm{p}<0.05$ 
Table XIII: Linear Regression for Customer Orientation towards Behavioural Intentions

\begin{tabular}{|l|c|}
\hline \multirow{2}{*}{ Variables } & Behavioural Intentions \\
\hline Perceived Value & $0.804^{* *}$ \\
\hline R & 0.804 \\
\hline R Square & 0.646 \\
\hline Adjusted R Square & 0.645 \\
\hline Durbin Watson & 1.851 \\
\hline
\end{tabular}

** Significant at least at $\mathrm{p}<0.05$

\section{Summary on Hypotheses Testing}

With the results obtained from linear regression analysis, the researcher had confirmed and summarised that all the hypotheses proposed in this research are approved and accepted. The hypotheses are as follows:

$\mathrm{H} 1$ : $\mathrm{CO}$ is positively related to customer satisfaction.

$\mathrm{H} 2$ : $\mathrm{CO}$ is positively related to $\mathrm{BI}$.

$\mathrm{H} 3$ : $\mathrm{SO}$ is positively related to customer satisfaction.

$\mathrm{H} 4$ : $\mathrm{SO}$ is positively related to $\mathrm{BI}$.

H5: SQ is positively related to customer satisfaction.

H6: SQ is positively related to $\mathrm{BI}$.

H7: SEQ is positively related to customer satisfaction.

H8: SEQ is positively related to BI.

H9: VAL is positively related to customer satisfaction.

H10: VAL is positively related to BI.

\section{Discussion}

Ultimately, all the objectives and hypotheses in this research which aimed to examine the direct relationship between the independent and dependent variables had been met and achieve. With the positive Beta value and $p$ value less than 0.05 obtained from the results of analyses, all the proposed hypotheses were accepted. Furthermore, with the R square value gained from previous chapter, the customer satisfaction and behavioural intention are highly depend on customer orientation and service orientation. $\mathrm{H} 1$ and $\mathrm{H} 3$ had illustrate that $\mathrm{CO}$ and SO is positively related to the customer orientation which means highly customer and service oriented service provider will result in great customer satisfaction and vice versa. This is because when employees are customer and service oriented, they will do their best in satisfying the customers' needs and always ensure that the services provided by them are in high quality. The positive impact of $\mathrm{CO}$ directly towards customer satisfaction had been proved by previous study (Stock and Hoyer, 2005). However, the direct influence of SO towards customer satisfaction without mediator is less tested in previous study.

With the approval of the $\mathrm{H} 2$ and $\mathrm{H} 4$, customer orientation and service orientation also held the key towards positive customers' behavioural intention. This behavioural intention basically consists of three dimensions: word-of-mouth, repurchase intention or revisit intention and feedback to the service provider. Same as customer satisfaction, if a customer is serve by a single or group of highly customer and service oriented retailer employees, the customer definitely will have positive word-of-mouth spreading among his/her friends and 
family. Besides that, the enjoyment and warm feeling felt by the customer will encourage them to repurchase and revisit the grocery stores frequently. Moreover, positive feedback will be given by the customer to the service provider too. Sadly, the testing on direct impact of $\mathrm{CO}$ and SO towards behavioural intention is less develops because scholars tend to add in other variables such as customer satisfaction as mediator in their research (Jayawardhena and Farrell, 2011).

As a conclusion, the approval and acceptance of $\mathrm{H} 7$ and $\mathrm{H} 8$ are unquestionable. Last but not least, perceived value had been identified to have positive impact towards customer satisfaction and behavioural intention in this study because the result from the linear regression analysis show a positive Beta value and $\mathrm{p}<0.05$. Hence, $\mathrm{H} 9$ and $\mathrm{H} 10$ are accepted. Besides the evidence from this study, previous study also proved that customer satisfaction is affected by the perceived value of pre-purchase and post-purchase (Eggert and Ulaga, 2002). This is because if the perceived value of the goods and services evaluated before and after purchasing are inadequate, undoubtedly the customer will feel dissatisfy. On the other hand, if the customers had a positive view of 'I get what I pay for' towards the grocery stores, they will definitely repurchase and revisit the stores again while at the same time forwarding their positive experiences to their friends and family (Eggert and Ulaga, 2002). What more to say provide positive feedback to their service provider. These findings were also supported by Cronin et al. (2000) where customer satisfaction and behavioural intention are predicted by perceived value.

\section{Managerial Application}

This research is very useful especially for the marketers of physical stores to understand the importance of providing good services to their customers and maybe to their potential customers too. Moreover, the positive relationship of customer orientation and service orientation towards the customer satisfaction and behavioural intentions had proved to the retail managers that they should not rely upon certain groups of employees that can perform well, but they should also emphasis on the individual-level of CO and SO. Besides that, due to the importance of $\mathrm{CO}$ and $\mathrm{SO}$, these constructs are recommended to be included as one of the requirements during the recruitment and selection process for retail employees and managers (Cran, 1994).

\section{Conclusion}

The purpose of this research was to explore and investigate the impacts of customer orientation, service orientation, service quality, service encounter quality, perceived value towards customer satisfaction and behavioural intention in retailing industry. Undeniable, managers and marketers in retailing industry are getting more aware of the customer satisfaction and customers' behavioural intention as the market is becoming more competitive. This situation not only happens to retailing industry but also to the entire services sector. As the matters of fact, customer satisfaction and behavioural intention had turn out to be scholars' favourite research topic. 


\section{References}

Andreassen, T.W., and Lindestad, B. (1998), Customer Loyalty and Complex Services: The impact of corporate image on quality, customer satisfaction and loyalty for customers with varying degrees of service expertise, International Journal of Service Industry Management, 9(1), pp. 7-23.

Bagozzi, R.P. (1992). The self-regulation of attitudes, intentions, and behaviour", Social Psychology Quarterly55(1), pp. 178-204.

Brace, N., Kemp, R. \&Snelgar, R. (2006) SPSS for Psychologists (3rd edition). Basingstoke: Lawrence Erlbaum Associates.

Chen, Z. \& Dubinsky, AJ. (2003).A conceptual model of perceived customer value in Ecommerce: a preliminary investigation. Psychol Mark, 20(4), pp. 323-347.

Churchill, G.A. \&Iacobucci, D. (2009).Marketing Research: Methodological Foundations, South-Western Cengage Learning, USA.

CIA, (2011), Country Comparison: GDP - Per Capita (PPP), Viewed 12th April 2012, $<$ https://www.cia.gov/library/publications/the-worldfactbook/rankorder/2004rank.html >.

Cran, D.J. (1994). Towards Validation of the Service Orientation Construct.Service Industries Journal, 14(1), pp. 34-44.

Cronin, J.J. \& Taylor, S.A. (1992). Measuring service quality: a re-examination and extension.Journal of Marketing.56(3), pp. 55-68.

Cronin, J.J., Brady, M.K., \&Hult, G.T. (2000).Assessing the effects of quality, value, customer satisfaction on consumer behavioral intentions in service environments.Journal of Retailing, 76(2), pp. 193-218.

Dawkins, P. \&Reichheld, F. (1990).Customer retention as a competitive weapon.Directors and Boards, 14(1), pp. 42-47.

DBKU 2011, City Boundary, viewed 5th November 2011, $<$ http://www.dbku.gov.my/Eng/boundry.htm>.

Eggert, A., \&Ulaga, W. (2002). Customer perceived value: A substitute for satisfaction in business markets? Journal of Business \& Industrial Marketing, 17(2/3), pp. 107118.

Fisher, R.J. (1991). Durable differentiation strategies for services.Journal of Services Marketing, 5(1), pp. 19-28.

Fornell, C., Johnson, M., Anderson, E. W., Cha, J. \&Everitt Bryant, B. (1996) The American customer satisfaction index: nature, purpose, and findings, Journal of Marketing, 60(October), pp. 7-18. 
Gómez, M.I., McLaughlin, E.W., \&Wittink, D. R. (2004). Customer satisfaction and retail sales performance: an empirical investigation. Journal of Retailing, 80(1), pp. 265278.

Hennig-Thurau, T. (2004), Customer-orientation of service employees: its impact on customer satisfaction, commitment, and retention, International Journal of Service Industry Management, 15(5), pp. 460-478.

Heskett, J.L., Sasser, W.E. \& Schlesinger, L.A. (1997). The Service Profit Chain: How Leading Companies Link Profit and Growth to Loyalty, Satisfaction, and Value. The Free Press, New York, NY.

Hoffman, K.D., Kelley, S.W., \&Rotalsky, H.M. (1995).Tracking service failures and employee recovery efforts.Journal of Services Marketing, 9(2), pp. 49-62.

Jayawardhena, C. \& Farrell, A.M. (2011). Effects of retail employees' behaviours on customers' service evaluation. International Journal of Retail \& Distribution Management, 39(2), pp. 203-217.

Kandampully, J. (1998). Service Quality to Service Loyalty: A Relationship which Goes Beyond Customer Services, Total Quality Management, 9(6).

Kassim, N.M., Mohammed, A.K. \& Abdulla, A. (2006) "The influence of attraction on internet banking: an extension to the trust-relationship commitment model", International Journal of Bank Marketing, 24(6), pp. 424 - 442

Luck, D. J., Taylor, W. G., \& Robin (1987).Marketing Research.Eaglewood: Prentice Hall. Lytle, R., \& Timmerman, J. (2006). Service orientation and performance: an organizational perspective. Journal of Services Marketing, 20(2), 136-147.

Patterson, P.G. (2004). A contingency model of behavioural intentions in a services context.European Journal of Marketing, 38(9), pp. 1304 - 1315.

Pelosi, M.K., Sandifer, T.M. \&Sekaran, U. (2000).Research and Evaluation for Business. John Wiley and Son Inc., New York.

Rust, R.T. \& Oliver, R.L. (1994). Service quality: insights and managerial implications from the frontier. In: Rust, R.T., Oliver, R.L. (Eds.), Service Quality: New Directions in Theory and Practice. Sage Publications, London, pp.1-19.

Ravald, A. \&Grönroos, C. (1996). The value concept and relationship.European Journal of Marketing, 30(2), pp. 19-30.

Reichheld, FF. \& Sasser, W.L. (1990). Zero defections: quality comes to services. Harvard Business Review, 68, pp. 105-111.

Saunders, M.N.K., Lewis, P. \&Thornhill, A. (2003) Research methods for business students $(3 r d E d)$. Harlow: FT Prentice Hall. 
Schlesinger, L. A., \& Heskett, J. L., (1991). The Service-Driven Service Company. Harvard Business Review, pp. 77-81.

Sekaran U. \&Bougie R. (2010).Research Methods for Business: A Skill Building Approach. John Wiley \& Sons, New York.

Woodruff, R.B. (1997) Customer value: the next source for competitive advantage. Journal Academic Marketing Science, 25(2), pp. 139-153.

Zeithaml, V.A., Parasuraman, A. and Berry, L.L. (1990).Delivering Quality Service: Balancing Customer Perceptions and Expectations.The Free Press, New York, NY. 